\title{
Alkyldihydropyrones, new polyketides synthesized by a type III polyketide synthase from Streptomyces reveromyceticus
}

\author{
Teruki Aizawa $^{1}$, Seung-Young Kim ${ }^{1}$, Shunji Takahashi ${ }^{2,3}$, Masahiko Koshita ${ }^{1}$, Mioka Tani ${ }^{1}$, Yushi Futamura ${ }^{3}$, \\ Hiroyuki Osada ${ }^{2,3}$ and Nobutaka Funa ${ }^{1}$
}

Genome sequencing allows a rapid and efficient identification of novel catalysts that produce novel secondary metabolites. Here we describe the catalytic properties of dihydropyrone synthase A (DpyA), a novel type III polyketide synthase encoded in a linear plasmid of Streptomyces reveromyceticus. Heterologous expression of dpyA led to the accumulation of alkyldihydropyrones A (1), B (2), C (3) and D (4), which are novel dihydropyran compounds that exhibit weak cytotoxicity against the leukemia cell line HL-60. DpyA catalyzes the condensation of $\beta$-hydroxyl acid thioester and methylmalonyl-CoA to yield a triketide intermediate that then undergoes lactonization of a secondary alcohol and a thioester to give alkyldihydropyrone.

The Journal of Antibiotics (2014) 67, 819-823; doi:10.1038/ja.2014.80; published online 2 July 2014

\section{INTRODUCTION}

Type III polyketide synthase (PKS), which is widely distributed among higher plants, fungi and bacteria, catalyzes the assembly of primary metabolites such as acyl-CoA compounds to synthesize structurally complex polyketides. ${ }^{1}$ The reaction catalyzed by type III PKS starts with the formation of a thioester bond between the catalytic center cysteine and an acyl group derived from a starter substrate. Decarboxylative condensation of an extender substrate toward a thioester linkage between the acyl group and the catalytic center cysteine extends the growing polyketide chain. With a few exceptions such as diketide synthase, which catalyzes hydrolysis of a polyketide chain, ${ }^{2}$ typical type III PKS enzymes catalyze cyclization of a polyketide chain to yield a monocyclic compound. The variety in the reactions catalyzed by type III PKSs can be attributed to the selectivity of starter and extender substrates, the condensation times and the pattern of cyclization. ${ }^{1}$

A number of type III PKSs have been identified from the genus Streptomyces. For example, RppA catalyzes condensation of five molecules of malonyl-CoA to synthesize 1,3,6,8-tetrahydroxynaphthalene, which is a key intermediate of hexahydroxyperylenequinone melanin biosynthesis in S. griseus. ${ }^{3,4}$ Germicidin synthase synthesizes germicidin in $S$. coelicolor A3(2) via the condensation of an acyl carrier protein ester of $\beta$-keto acid and ethylmalonyl-CoA. ${ }^{5}$ SrsA synthesizes alkylresorcinols by sequential and order-controlled condensation of malonyl-CoA, malonyl-CoA and methylmalonylCoA toward long-chain acyl-CoA in S. griseus. ${ }^{6} \mathrm{Ken} 2$, a homolog of DpgA, ${ }^{7-9}$ which synthesizes 3,5-dihydroxyphenylacetyl-CoA, was found in a kendomycin biosynthetic gene cluster of S. violaceoruber. ${ }^{10}$
Very recently, Tang et al. ${ }^{11}$ discovered that presulficidin, which is synthesized by Cpz6, a type III PKS from the caprazamycin biosynthetic cluster, relays sulfonate from $3^{\prime}$-phosphoadenine- $5^{\prime}$ phosphosulfate to caprazamycin.

Genome sequence analyses of Streptomyces species have shown that the number of biosynthetic gene clusters encoded on the chromosome is much higher than the number of secondary metabolites isolated from each species. ${ }^{12,13}$ The genome of $S$. reveromyceticus $\mathrm{SN}-593$ was sequenced in the course of the studies of the biosynthesis of reveromycin $\mathrm{A}$, which inhibits bone resorption and bone metastases of tumor cells. ${ }^{14-16}$ Analysis of the draft genome data of S. reveromyceticus revealed that a type III PKS named DpyA is encoded on a linear plasmid derived from this bacterium. In this study, we demonstrate that DpyA catalyzes the synthesis of the novel dihydropyran compounds alkyldihydropyrone A-D (Figure 1) from $\beta$-hydroxyl acid thioesters and methylmalonyl-CoA, both in vivo and in vitro. DpyA preferentially uses the $\beta$-hydroxyl acid thioester rather than the $\beta$-keto acid thioester as a starter substrate. A unique feature of DpyA is an ability to catalyze lactonization of secondary alcohols and thioesters. In addition, alkyldihydropyrones showed weak cytotoxicity against the leukemia cell line HL-60.

\section{MATERIALS AND METHODS}

General

Media, growth conditions and general recombinant DNA techniques of Escherichia coli and Streptomyces were described by Sambrook et al. ${ }^{17}$ and Kieser et al., ${ }^{18}$ respectively. E. coli HST04 and HST08, restriction enzymes and other DNA-modifying enzymes used for DNA manipulation were purchased

${ }^{1}$ Graduate Division of Nutritional and Environmental Sciences, University of Shizuoka, Shizuoka, Japan; ${ }^{2}$ Chemical Biology Research Group, RIKEN Center for Sustainable Resource Science, Saitama, Japan and ${ }^{3}$ Antibiotics Laboratory, RIKEN, Saitama, Japan

Correspondence: Professor N Funa, Graduate Division of Nutritional and Environmental Sciences, University of Shizuoka, 52-1, Yada, Suruga, Shizuoka 422-8526, Japan. E-mail: funa@u-shizuoka-ken.ac.jp

Received 23 January 2014; revised 22 April 2014; accepted 27 May 2014; published online 2 July 2014 
<smiles>[R]C1CC(O)=C(C)C(=O)O1</smiles>

alkyldihydropyrone A (1): R = isopentyl alkyldihydropyrone $\mathrm{B} \quad(2): \mathrm{R}=n$-pentyl alkyldihydropyrone C (3): R = 3-methylpentyl alkyldihydropyrone D (4): $\mathrm{R}=$ isohexyl

Figure 1 Structures of alkyldihydropyrone A-D (1-4).

from Takara Biochemicals (Shiga, Japan). E. coli ASKA clone ( -) JW1079 was obtained from the National BioResource Project (National Institute of Genetics of Japan). HR-MS were measured using a JEOL AccuTOF-DART mass spectrometer (JEOL, Tokyo, Japan). ${ }^{1} \mathrm{H},{ }^{13} \mathrm{C}$ and $2 \mathrm{D}$ NMR spectra of alkyldihydropyrones were measured in $\mathrm{CD}_{3} \mathrm{OD}$ on a Bruker BioSpin AV400N FT-NMR spectrometer (Bruker, Billerica, MA, USA). Optical rotations of alkyldihydropyrones were measured on a JASCO P-2200 digital polarimeter (JASCO, Tokyo, Japan). IR spectra of alkyldihydropyrones were measured on a JASCO FT/IR-550 spectrometer (JASCO). UV spectra of alkyldihydropyrones were measured on a JASCO V-630BIO spectrophotometer (JASCO).

\section{Construction of pIJ6021-SRE2_11 and pIJ4123-SRE2_11}

An NdeI site was introduced at the start codon of $d p y A$ by PCR with primer I: $5^{\prime}$-GCGGAATTCCATATGGCTGCCTATGTGAGCTG-3' (the EcoRI site is underlined; the $N d e I$ site is italicized; the boldface letter indicates the silent mutation introduced to abolish the native NdeI site), and primer II: $5^{\prime}$-GCGGGATCCGACCTGGACTGACCATCA- $3^{\prime}$ (the BamHI site is italicized). The amplified fragment was cloned between the EcoRI and BamHI sites of pUC19, resulting in pUC19-SRE2_11. DNA sequencing of the plasmid confirmed the correct sequence. The NdeI-Bam HI fragment excised from pUC19-SRE2_11 was cloned between the NdeI and BamHI sites of pIJ6021 and pIJ4123,19 resulting in pIJ6021-SRE2_11 and pIJ4123-SRE2_11, respectively.

\section{HPLC analysis of alkyldihydropyrones produced by Streptomyces} S. coelicolor M1146/pIJ6021-SRE2_11 was used to inoculate $50 \mathrm{ml}$ of yeast extract-malt extract liquid medium containing $5 \mu \mathrm{g} \mathrm{ml}^{-1}$ of kanamycin, and the resultant culture was grown at $30^{\circ} \mathrm{C}$. After $24 \mathrm{~h}, 5 \mu \mathrm{g} \mathrm{ml}^{-1}$ of thiostrepton was added to induce the tip promoter, and the culture was continued for a further $48 \mathrm{~h}$. A $2 \mathrm{ml}$ aliquot of the supernatant from the broth culture was acidified with $30 \mu \mathrm{l}$ of $6 \mathrm{M} \mathrm{HCl}$ and extracted with ethyl acetate. The ethyl acetate phase was evaporated and the residue was dissolved in a small amount of methanol. Reverse-phase HPLC analysis was carried out using a Docosil B column $(4.6 \times 250 \mathrm{~mm}$; Senshu Scientific, Tokyo, Japan). Fractions eluted with a gradient of $10-90 \%$ acetonitrile in water (both containing $0.1 \%$ trifluor-

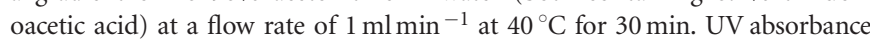
was detected at $254 \mathrm{~nm}$.

\section{Large-scale preparation of polyketides produced by $S$. coelicolor M1146/pIJ6021-SRE2_11}

S. coelicolor M1146/pIJ6021-SRE2_11 was used to inoculate $2 \times 1$ liter of yeast extract-malt extract liquid medium containing $5 \mu \mathrm{g} \mathrm{ml}^{-1}$ of kanamycin, and grown at $30^{\circ} \mathrm{C}$. After $24 \mathrm{~h}, 5 \mu \mathrm{g} \mathrm{ml}^{-1}$ of thiostrepton was added and the culture was continued for a further $72 \mathrm{~h}$. The $\mathrm{pH}$ of the culture supernatant was adjusted to 2.0 with $6 \mathrm{M} \mathrm{HCl}$, and then extraction was carried out using ethyl acetate. The organic layer was washed with brine, dried over anhydrous sodium sulfate and evaporated until dry. The crude materials were dissolved in a small amount of acetone and flash chromatographed on silica gel using benzene/acetone $(1: 1, \mathrm{vol} / \mathrm{vol})$ as an eluent. The eluate was evaporated and dissolved in methanol for reverse-phase preparative HPLC. The crude materials were purified using a reverse-phase preparative HPLC apparatus equipped with a $5 \mathrm{C}_{18}$-AR-II column $\left(20 \times 250 \mathrm{~mm}^{2}\right.$; Nacalai Tesque, Kyoto, Japan) by elution with a gradient of methanol in water containing $0.1 \%$ trifluoroacetic acid, at a flow rate of $5 \mathrm{ml} \mathrm{min}^{-1}$ at ambient temperature. The elution conditions were as follows: $10-70 \%$ methanol for $50 \mathrm{~min}$, followed by $70-100 \%$ methanol for $40 \mathrm{~min}$. After lyophilization, the compounds were further purified using a recycle HPLC system equipped with a Docosil SP-100 column $(10 \times 250 \mathrm{~mm}$; Senshu Scientific). Compounds 1 and 2 were eluted with $45 \%$ acetonitrile and $0.1 \%$ trifluoroacetic acid in water, whereas compounds 3 and 4 were eluted with 55\% methanol and $0.1 \%$ trifluoroacetic acid in water, at a flow rate of $3 \mathrm{ml} \mathrm{min}^{-1}$ at ambient temperature. The collected fractions were lyophilized to give $\mathbf{1}$ to $\mathbf{4}$ as white solids. The yields of 1, 2, 3 and 4 were 19, 18, 7 and $4 \mathrm{mg}$, respectively.

\section{Physicochemical properties of alkyldihydropyrones}

5,6-dihydro-4-hydroxy-6-isopentyl-3-methyl-2H-pyran-2-one (1). ${ }^{1} \mathrm{H} \quad \mathrm{NMR}$ $\left(400 \mathrm{MHz}, \mathrm{CD}_{3} \mathrm{OD}\right): \delta 0.92\left(\mathrm{~d}, 6 \mathrm{H}, J=6.6 \mathrm{~Hz}, \mathrm{C}^{\prime} \mathrm{H}_{3}\right.$ and $\left.\mathrm{C}^{\prime}-\mathrm{CH}_{3}\right), 1.26$ $\left(\mathrm{m}, 1 \mathrm{H}, \mathrm{C} 2^{\prime} \mathrm{Ha}\right), 1.41\left(\mathrm{~m}, 1 \mathrm{H}, \mathrm{C} 2^{\prime} \mathrm{Hb}\right), 1.57\left(\mathrm{~m}, 1 \mathrm{H}, \mathrm{C} 3^{\prime} \mathrm{H}\right), 1.61-1.75(\mathrm{~m}, 2 \mathrm{H}$, $\left.\mathrm{Cl}^{\prime} \mathrm{H}_{2}\right), 1.71\left(\mathrm{~s}, 3 \mathrm{H}, \mathrm{C} 3-\mathrm{CH}_{3}\right), 2.41(\mathrm{ddd}, 1 \mathrm{H}, J=0.7,4.3$ and $17.1 \mathrm{~Hz}, \mathrm{C} 5 \mathrm{Ha})$, $2.52(\mathrm{ddd}, 1 \mathrm{H}, J=1.8,11.8$ and $17.1 \mathrm{~Hz}, \mathrm{C} 5 \mathrm{Hb}), 4.30(\mathrm{~m}, 1 \mathrm{H}, \mathrm{C} 6 \mathrm{H}) ;{ }^{13} \mathrm{C} \mathrm{NMR}$ $\left(100 \mathrm{MHz}, \mathrm{CD}_{3} \mathrm{OD}\right): \delta 8.6\left(\mathrm{C}^{-}-\mathrm{CH}_{3}\right), 22.8\left(\mathrm{C}^{\prime}\right.$ and $\left.\mathrm{C3}^{\prime}-\mathrm{CH}_{3}\right), 29.1\left(\mathrm{C}^{\prime}\right), 33.7$ $\left(\mathrm{Cl}^{\prime}\right), 34.2(\mathrm{C} 5), 35.1\left(\mathrm{C}^{\prime}\right), 76.8(\mathrm{C} 6), 99.0(\mathrm{C} 3), 168.1(\mathrm{C} 4)$ and $172.5(\mathrm{C} 2)$; positive mode direct analysis in real time-time of flight-mass spectrum (DART/ TOF-MS), $m / z \quad 199.13163$ (calculated for $\mathrm{C}_{11} \mathrm{H}_{19} \mathrm{O}_{3}, 199.13342$ ); $[\alpha]_{\mathrm{D}}^{20}-41$ (c 0.64, $\left.\mathrm{CH}_{3} \mathrm{OH}\right)$; IR $v_{\max }{ }^{\mathrm{KBr}} 3102,2955,2863$ and $1602 \mathrm{~cm}^{-1}$; UV $\left(\mathrm{CH}_{3} \mathrm{OH}\right)$ $\lambda_{\max }(\log \varepsilon) 249 \mathrm{~nm}(1.12)$. These underlined ' $\mathrm{C}$ ' mean that the signals are assigned for the underlined ' $\mathrm{C}$ ' but not for $\mathrm{C} 3$.

5,6-dihydro-4-hydroxy-3-methyl-6-pentyl-2H-pyran-2-one $\quad$ (2). ${ }^{1} \mathrm{H} \quad \mathrm{NMR}$ $\left(400 \mathrm{MHz}, \mathrm{CD}_{3} \mathrm{OD}\right): \delta 0.91\left(\mathrm{t}, 3 \mathrm{H}, J=6.9 \mathrm{~Hz}, \mathrm{C}^{\prime} \mathrm{H}_{3}\right), 1.34\left(\mathrm{~m}, 4 \mathrm{H}, \mathrm{C}^{\prime} \mathrm{H}_{2}\right.$ and $\left.\mathrm{C}^{\prime} \mathrm{H}_{2}\right), 1.38\left(\mathrm{~m}, 1 \mathrm{H}, \mathrm{C} 2^{\prime} \mathrm{Ha}\right), 1.51\left(\mathrm{~m}, 1 \mathrm{H}, \mathrm{C} 2^{\prime} \mathrm{Hb}\right), 1.62\left(\mathrm{~m}, 1 \mathrm{H}, \mathrm{Cl}^{\prime} \mathrm{Ha}\right)$, $1.70\left(\mathrm{~s}, 3 \mathrm{H}, \mathrm{C} 3-\mathrm{CH}_{3}\right), 1.73\left(\mathrm{~m}, 1 \mathrm{H}, \mathrm{Cl}^{\prime} \mathrm{Hb}\right), 2.40$ (ddd, $1 \mathrm{H}, J=0.8,4.3$ and $17.1 \mathrm{~Hz}, \mathrm{C} 5 \mathrm{Ha}), 2.50$ (ddd, $1 \mathrm{H}, J=1.8,11.8$ and $17.1 \mathrm{~Hz}, \mathrm{C} 5 \mathrm{Hb}), 4.31(\mathrm{~m}, 1 \mathrm{H}$, $\mathrm{C} 6 \mathrm{H}) ;{ }^{13} \mathrm{C}$ NMR $\left(100 \mathrm{MHz}, \mathrm{CD}_{3} \mathrm{OD}\right): \delta 8.6\left(\mathrm{C}^{-}-\mathrm{CH}_{3}\right), 14.3\left(\mathrm{C5}^{\prime}\right), 23.6\left(\mathrm{C4}^{\prime}\right)$, $25.7\left(\mathrm{C}^{\prime}\right), 32.7\left(\mathrm{C}^{\prime}\right), 34.5(\mathrm{C} 5), 35.8\left(\mathrm{Cl}^{\prime}\right), 76 . \overline{6}(\mathrm{C} 6), 98.7(\mathrm{C} 3), 168.8(\mathrm{C} 4)$ and 172.7 (C2); positive mode DART/TOF-MS, $\mathrm{m} / \mathrm{z} 199.13169$ (calculated for $\left.\mathrm{C}_{11} \mathrm{H}_{19} \mathrm{O}_{3}, 199.13342\right) ;[\alpha]_{\mathrm{D}}^{20}-19$ (c 0.72, $\left.\mathrm{CH}_{3} \mathrm{OH}\right) ; \mathrm{IR} v_{\max }{ }^{\mathrm{KBr}} 3111,2955,2934$, 2863 and $1597 \mathrm{~cm}^{-1}$; UV $\left(\mathrm{CH}_{3} \mathrm{OH}\right) \lambda_{\max }(\log \varepsilon) 248 \mathrm{~nm}(0.81)$.

5,6-dihydro-4-hydroxy-3-methyl-6-(3'-methylpentyl)-2H-pyran-2-one $\quad(3) . \quad{ }^{1} \mathrm{H}$ NMR $\left(400 \mathrm{MHz}, \mathrm{CD}_{3} \mathrm{OD}\right): \delta 0.89\left(\mathrm{t}, 3 \mathrm{H}, J=7.1 \mathrm{~Hz}, \mathrm{C}^{\prime} \mathrm{H}_{3}\right), 0.89$ (d, $3 \mathrm{H}$, $\left.J=6.5 \mathrm{~Hz}, \mathrm{C}^{\prime}-\mathrm{CH}_{3}\right), 1.18\left(\mathrm{~m}, 1 \mathrm{H}, \mathrm{C}^{\prime} \mathrm{Ha}\right), 1.27-1.46\left(\mathrm{~m}, 3 \mathrm{H}, \mathrm{C}^{\prime} \mathrm{Ha}, \mathrm{C}^{\prime} \mathrm{H}\right.$ and $\left.\mathrm{C}^{\prime} \mathrm{Hb}\right), 1.50-1.65\left(\mathrm{~m}, 2 \mathrm{H}, \mathrm{Cl}^{\prime} \mathrm{Ha}\right.$ and $\left.\mathrm{C}^{\prime} \mathrm{Hb}\right), 1.70\left(\mathrm{~s}, 3 \mathrm{H}, \mathrm{C} 3-\mathrm{CH}_{3}\right), 1.75$ (m, $1 \mathrm{H}, \mathrm{Cl}^{\prime} \mathrm{Hb}$ ), 2.41 (ddd, $\left.1 \mathrm{H}, J=0.7,4.3,17.1 \mathrm{~Hz}, \mathrm{C} 5 \mathrm{Ha}\right), 2.51$ (ddd, $1 \mathrm{H}$, $J=1.6,13.1$ and $17.1 \mathrm{~Hz}, \mathrm{C} 5 \mathrm{Hb}), 4.30(\mathrm{~m}, 1 \mathrm{H}, \mathrm{C} 6 \mathrm{H}) ;{ }^{13} \mathrm{C} \mathrm{NMR}(100 \mathrm{MHz}$, $\left.\mathrm{CD}_{3} \mathrm{OD}\right): \delta 8.6\left(\mathrm{C}^{-} \mathrm{CH}_{3}\right), 11.7\left(\mathrm{C}^{\prime}\right), 19.4\left(\mathrm{C3}^{\prime}-\mathrm{CH}_{3}\right), 30.5\left(\mathrm{C}^{\prime}\right), 32.7\left(\mathrm{C}^{\prime}\right)$, $33.3\left(\mathrm{Cl}^{\prime}\right), 34.2(\mathrm{C} 5), 35.5\left(\mathrm{C}^{\prime}\right), 76.9(\mathrm{C} 6), 99.0(\mathrm{C} 3), 168.1(\mathrm{C} 4)$ and 172.6 (C2); positive mode DART/TOF-MS, $m / z 213.14548$ (calculated for $\mathrm{C}_{12} \mathrm{H}_{21} \mathrm{O}_{3}$, 213.14907); $[\alpha]_{D^{-}}^{20}-52$ (c 0.52, $\left.\mathrm{CH}_{3} \mathrm{OH}\right)$; IR $v_{\max } \mathrm{KBr}^{2} 3111,2959,2926,2870$ and $1717 \mathrm{~cm}^{-1} ; \mathrm{UV}\left(\mathrm{CH}_{3} \mathrm{OH}\right) \lambda_{\max }(\log \varepsilon) 246 \mathrm{~nm}(0.444)$.

5,6-dihydro-4-hydroxy-3-methyl-6-(4'-methylpentyl)-2H-pyran-2-one (4). ${ }^{1} \mathrm{H}$ NMR $\left(400 \mathrm{MHz}, \mathrm{CD}_{3} \mathrm{OD}\right): \delta 0.91\left(\mathrm{~d}, 6 \mathrm{H}, J=6.6 \mathrm{~Hz}, \mathrm{C}^{\prime} \mathrm{H}_{3}\right.$ and $\left.\mathrm{C}^{\prime}-\mathrm{CH}_{3}\right)$, $1.22\left(\mathrm{~m}, 2 \mathrm{H}, \mathrm{C}^{\prime} \mathrm{H}_{2}\right), 1.41\left(\mathrm{~m}, 1 \mathrm{H}, \mathrm{C} 2^{\prime} \mathrm{Ha}\right), 1.51-1.57\left(\mathrm{~m}, 2 \mathrm{H}, \mathrm{C} 2^{\prime} \mathrm{Hb}\right.$ and $\left.\mathrm{C}^{\prime} \mathrm{H}\right), 1.60\left(\mathrm{~m}, 1 \mathrm{H}, \mathrm{Cl}^{\prime} \mathrm{Ha}\right), 1.70\left(\mathrm{~s}, 3 \mathrm{H}, \mathrm{C} 3-\mathrm{CH}_{3}\right), 1.72\left(\mathrm{~m}, 1 \mathrm{H}, \mathrm{Cl}^{\prime} \mathrm{Hb}\right), 2.41$ (ddd, $1 \mathrm{H}, J=0.7,3.8$ and $17.1 \mathrm{~Hz}, \mathrm{C} 5 \mathrm{Ha}), 2.51(\mathrm{ddd}, 1 \mathrm{H}, J=1.4,11.7$ and $17.1 \mathrm{~Hz}, \mathrm{C} 5 \mathrm{Hb}), 4.33(\mathrm{~m}, 1 \mathrm{H}, \mathrm{C} 6 \mathrm{H}) ;{ }^{13} \mathrm{C} \mathrm{NMR}\left(100 \mathrm{MHz}, \mathrm{CD}_{3} \mathrm{OD}\right): \delta 8.6$ $\left(\mathrm{C} 3-\mathrm{CH}_{3}\right), 22.9\left(\mathrm{C}^{\prime}\right.$ and $\left.\mathrm{C}^{\prime}-\mathrm{CH}_{3}\right), 23.8\left(\mathrm{C}^{\prime}\right), 29.1\left(\mathrm{C} 4^{\prime}\right), 34.2(\mathrm{C} 5), 36.0$ $\left(\mathrm{Cl}^{\prime}\right), 39.9\left(\mathrm{C}^{\prime}\right), 76.6(\mathrm{C} 6), 9 \overline{9} .0(\mathrm{C} 3), 168.2(\mathrm{C} 4)$ and $172.6(\mathrm{C} 2)$; positive mode DART/TOF-MS, $m / z 213.14623$ (calculated for $\mathrm{C}_{12} \mathrm{H}_{21} \mathrm{O}_{3}, 213.14907$ ); $[\alpha]_{\mathrm{D}^{2}}-59\left(c 0.47, \mathrm{CH}_{3} \mathrm{OH}\right)$; IR $v_{\max }{ }^{\mathrm{KBr}} 3111,2954,2926,2862$ and $1725 \mathrm{~cm}^{-1}$; $\mathrm{UV}\left(\mathrm{CH}_{3} \mathrm{OH}\right) \lambda_{\max }(\log \varepsilon) 245 \mathrm{~nm}(0.546)$.

\section{Production and purification of recombinant DpyA protein}

For production of N-terminus His-tagged DpyA, S. lividans TK21 harboring pIJ4123-SRE2_11 was used to inoculate $50 \mathrm{ml}$ of yeast extract-malt extract liquid medium containing $5 \mu \mathrm{g} \mathrm{ml}^{-1}$ of kanamycin, and the resultant culture was grown at $30^{\circ} \mathrm{C}$. After $24 \mathrm{~h}, 5 \mu \mathrm{g} \mathrm{ml}^{-1}$ of thiostrepton was added and the culture was continued for a further $24 \mathrm{~h}$. The cells were collected by centrifugation, and a crude cell lysate was prepared by sonication and removal of cell debris by centrifugation at $20000 \mathrm{~g}$ for $10 \mathrm{~min}$. Recombinant DpyA 
was purified to homogeneity (Supplementary Figure S1) by using a Ni-nitrilotriacetic acid column (Qiagen, Hilden, Germany), according to the manual from the manufacturer. The recombinant protein was dialyzed two times against 21 of $10 \mathrm{~mm}$ Tris- $\mathrm{HCl}$ buffer ( $\mathrm{pH}$ 7.5) containing $10 \%$ glycerol. The protein concentration was measured by Bradford assay with a Bio-Rad Protein Assay Kit (Bio-Rad Laboratories, Hercules, CA, USA) using bovine serum albumin as a standard.

\section{Synthesis of ( \pm )-3-hydroxyoctanoic acid $S$-(2'-acetamidoethyl) ester (5)}

A solution of ( \pm )-3-hydroxyoctanoic acid (100 mg, $0.624 \mathrm{mmol})$, 4-methylaminopyridine $\quad(20.1 \mathrm{mg}, \quad 0.164 \mathrm{mmol}), \quad N$-acetylcysteamine $\quad(81.8 \mathrm{mg}$, $0.686 \mathrm{mmol})$ and 1-ethyl-3-(3'-dimethylaminopropyl)carbodiimide hydrochloride $(132 \mathrm{mg}, 0.689 \mathrm{mmol})$ in $5 \mathrm{ml}$ dichloromethane was stirred at room temperature overnight. The reaction was quenched with ice, and the organic phase was separated. The aqueous phase was extracted three times with a portion of dichloromethane. The combined organic phase was washed with $1 \mathrm{M} \mathrm{HCl}$, and then with brine, dried over anhydrous sodium sulfate and the solvent was evaporated under reduced pressure. The residue was chromatographed by silica gel using hexane/ethyl acetate $(10: 1, \mathrm{vol} / \mathrm{vol})$ as a solvent to give $74 \mathrm{mg}(0.283 \mathrm{mmol})$ of $( \pm)-5$ as a colorless oil. ${ }^{1} \mathrm{H} \mathrm{NMR}(400 \mathrm{MHz}$, $\left.\mathrm{CDCl}_{3}\right): \delta 0.87\left(\mathrm{t}, 3 \mathrm{H}, J=6.8 \mathrm{~Hz}, \mathrm{C} 8 \mathrm{H}_{3}\right), 1.20-1.53\left(\mathrm{~m}, 8 \mathrm{H}, \mathrm{C}_{4} \mathrm{H}_{2}, \mathrm{C} 5 \mathrm{H}_{2}\right.$, $\mathrm{C} \mathrm{H}_{2}$ and $\left.\mathrm{C}_{7} \mathrm{H}_{2}\right), 1.95\left(\mathrm{~s}, 3 \mathrm{H}, \mathrm{CH}_{3}\right.$ of acetyl), $2.66(\mathrm{dd}, 1 \mathrm{H}, J=8.6,15.4 \mathrm{~Hz}$, $\mathrm{C} 2 \mathrm{H}), 2.74(\mathrm{dd}, 1 \mathrm{H}, J=3.4,15.4 \mathrm{~Hz}, \mathrm{C} 2 \mathrm{H}), 3.03\left(\mathrm{~m}, 2 \mathrm{H}, \mathrm{Cl}^{\prime} \mathrm{H}_{2}\right), 3.44(\mathrm{~m}, 2 \mathrm{H}$, $\left.\mathrm{C}^{\prime} \mathrm{H}_{2}\right), 4.04(\mathrm{~m}, 1 \mathrm{H}, \mathrm{C} 3 \mathrm{H})$ and $5.78(\mathrm{br} \mathrm{s}, 1 \mathrm{H}, \mathrm{NH})$. Positive mode DART/ TOF-MS, $m / z 262.14910$ (calculated for $\mathrm{C}_{12} \mathrm{H}_{24} \mathrm{NO}_{3} \mathrm{~S}, 262.14769$ ).

\section{Synthesis of 3-oxooctanoic acid $S$-(2'-acetamidoethyl) ester (6)}

A solution of Meldrum's acid $(1.00 \mathrm{~g}, 6.94 \mathrm{mmol})$ and pyridine $(1.10 \mathrm{~g}$, $13.9 \mathrm{mmol}$ ) in $5 \mathrm{ml}$ of ice-cooled dichloromethane was added hexanoyl chloride $(1.03 \mathrm{~g}, 7.65 \mathrm{mmol})$. The reaction mixture was stirred for $1 \mathrm{~h}$ at $0{ }^{\circ} \mathrm{C}$, and then allowed to warm to room temperature for $1 \mathrm{~h}$. The reaction was quenched with ice, and the organic phase was separated. The aqueous phase was extracted two times with dichloromethane. The combined organic phase was washed with brine, dried over anhydrous sodium sulfate and the solvent was evaporated under reduced pressure. The resultant oil was chromatographed on a silica gel using hexane/ethyl acetate $(10: 1, \mathrm{vol} / \mathrm{vol})$ as a solvent to give $887 \mathrm{mg}(3.66 \mathrm{mmol})$ of 5-hexanoyl-2,2-dimethyl-1,3-dioxane-4,6-dione as a pale yellow oil. ${ }^{1} \mathrm{H}$ NMR $\left(400 \mathrm{MHz}, \mathrm{CDCl}_{3}\right): \delta 0.84(\mathrm{t}, 3 \mathrm{H}, J=7.0 \mathrm{~Hz}$, $\left.\mathrm{C}^{\prime} \mathrm{H}_{3}\right), 1.30-1.35\left(\mathrm{~m}, 4 \mathrm{H}, \mathrm{C} 4^{\prime} \mathrm{H}_{2}\right.$ and $\left.\mathrm{C}^{\prime} \mathrm{H}_{2}\right), 1.59\left(\mathrm{~m}, 2 \mathrm{H}, \mathrm{C}^{\prime} \mathrm{H}_{2}\right), 1.67$ $\left(\mathrm{s}, 6 \mathrm{H}, \mathrm{C} 2-\left(\mathrm{CH}_{3}\right)_{2}\right)$ and $3.00\left(\mathrm{t}, 2 \mathrm{H}, J=7.6 \mathrm{~Hz}, \mathrm{C} 2^{\prime} \mathrm{H}_{2}\right)$. A solution of $\mathrm{N}$-acetylcysteamine $(236 \mathrm{mg}, 1.98 \mathrm{mmol}$ ) and 5-hexanoyl-2,2-dimethyl-1,3dioxane-4,6-dione $(698 \mathrm{mg}, 2.88 \mathrm{mmol})$ in anhydrous benzene $(20 \mathrm{ml})$ was refluxed for $5 \mathrm{~h}$. After evaporation under reduced pressure, the resultant oil was chromatographed on a silica gel using hexane/ethyl acetate $(10: 1, \mathrm{vol} / \mathrm{vol})$ as a solvent to give $229 \mathrm{mg}(0.88 \mathrm{mmol})$ of 6 as a white solid. NMR analysis indicates that the product exists predominantly as a keto form. ${ }^{1} \mathrm{H}$ NMR $\left(400 \mathrm{MHz}, \mathrm{CDCl}_{3}\right): \delta 0.83\left(\mathrm{t}, 3 \mathrm{H}, J=7.0 \mathrm{~Hz}, \mathrm{C} \mathrm{H}_{3}\right), 1.20-1.28\left(\mathrm{~m}, 4 \mathrm{H}, \mathrm{C} 6 \mathrm{H}_{2}\right.$ and $\left.\mathrm{C}_{7} \mathrm{H}_{2}\right), 1.53\left(\mathrm{~m}, \mathrm{C}^{2} \mathrm{H}_{2}\right), 1.92\left(\mathrm{~s}, 3 \mathrm{H}, \mathrm{CH}_{3}\right.$ of acetyl), $2.47(\mathrm{t}, 2 \mathrm{H}, J=7.4$ $\left.\mathrm{Hz}, \mathrm{C}_{4} \mathrm{H}_{2}\right), 3.03\left(\mathrm{t}, 2 \mathrm{H}, J=6.3 \mathrm{~Hz}, \mathrm{Cl}^{\prime} \mathrm{H}_{2}\right), 3.38\left(\mathrm{t}, 2 \mathrm{H}, J=6.3 \mathrm{~Hz}, \mathrm{C}^{\prime} \mathrm{H}_{2}\right)$, $3.64\left(\mathrm{~s}, 1 \mathrm{H}, \mathrm{C}_{2} \mathrm{H}_{2}\right)$ and 6.25 (br s, $\left.1 \mathrm{H}, \mathrm{NH}\right)$. Positive mode DART/TOF-MS, $m / z 260.12904$ (calculated for $\mathrm{C}_{12} \mathrm{H}_{22} \mathrm{NO}_{3} \mathrm{~S}, 260.12867$ ).

\section{Preparation of $(S)$ - and $(R)$-3-hydroxyoctanoic acid $S$ - $\left(2^{\prime}-\right.$} acetamidoethyl) ester (5)

Recombinant FabG was prepared from E. coli ASKA clone (-) JW1079. JW1079 was inoculated into $100 \mathrm{ml}$ of LB (Lysogeny Broth) liquid medium containing $12.5 \mathrm{\mu g} \mathrm{ml}^{-1}$ of chloramphenicol, and grown at $37^{\circ} \mathrm{C}$. After $6 \mathrm{~h}$, $0.1 \mathrm{~mm}$ of isopropyl $\beta$-D-1-thiogalactopyranoside was added, and the culture was continued for a further $24 \mathrm{~h}$. The cells were collected by centrifugation, and a crude cell lysate was prepared by sonication and removal of cell debris by centrifugation at $20000 \mathrm{~g}$ for $10 \mathrm{~min}$. Recombinant FabG protein was purified using a Ni-nitrilotriacetic acid column (Qiagen). The solution, which contained $100 \mathrm{~mm}$ Tris- $\mathrm{HCl}$ ( $\mathrm{pH} 7.5$ ), $4.2 \mu \mathrm{m}$ of recombinant FabG, $500 \mu \mathrm{M}$ $\mathrm{NADPH}$ and $500 \mu \mathrm{m} 3$-oxooctanoic acid $S$-(2-acetamidoethyl) ester (6), was stirred overnight at $30^{\circ} \mathrm{C}$. The reaction mixture was extracted with ethyl acetate, and the organic layer was evaporated under reduced pressure to give a residue that was chromatographed on silica gel as described above. The formation of $(R)-\mathbf{5}$ was confirmed by HR-MS analysis; positive mode DART/ TOF-MS, $m / z 262.14939$ (calculated for $\mathrm{C}_{12} \mathrm{H}_{24} \mathrm{NO}_{3} \mathrm{~S}, 262.14769$ ). The optical purity of $(R)-5$ was confirmed by chiral chromatography (Supplementary Figure S2). (S)-5 was prepared by chiral chromatography of $( \pm)-\mathbf{5}$ (Supplementary Figure S2).

\section{In vitro reaction of DpyA}

The reactions, which contained $100 \mathrm{~mm}$ Tris- $\mathrm{HCl}(\mathrm{pH}$ 7.5), $1.1 \mu \mathrm{m}$ of recombinant DpyA, $10 \mu \mathrm{m}$ of starter substrate and $10 \mu \mathrm{m}$ of methylmalonyl$\mathrm{CoA}$, were performed in a total volume of $500 \mu \mathrm{l}$. The reaction mixtures were incubated at $30^{\circ} \mathrm{C}$ for $1 \mathrm{~h}$ before being quenched by $30 \mu \mathrm{l}$ of $6 \mathrm{M} \mathrm{HCl}$, and extracted with $500 \mu$ l of ethyl acetate. The organic layer was evaporated, and the residue was dissolved in $20 \mu \mathrm{l}$ of methanol for HPLC analysis. The conditions for analytical and chiral HPLC were as described above.

\section{Determination of kinetic parameters of DpyA}

The reactions, which contained $100 \mathrm{~mm}$ Tris- $\mathrm{HCl}(\mathrm{pH} 7.5),(R)-\mathbf{5}$ or $\mathbf{6}, 200 \mu \mathrm{M}$ methylmalonyl-CoA and $2 \mu \mathrm{M}$ DpyA, were performed in a total volume of $200 \mu$ l. The concentrations of $(R)-5$ and $\mathbf{6}$ were varied between $20-300$ and $10-400 \mu \mathrm{M}$, respectively. The reactions were initiated by adding $(R)-5$ or 6 and continued for 4-32 min, and stopped with $30 \mu \mathrm{l}$ of $6 \mathrm{M} \mathrm{HCl}$, and the material in the mixture was extracted with ethyl acetate. The organic layer was collected and evaporated. The residual material was dissolved in $20 \mu \mathrm{l}$ of methanol for HPLC analysis. Reverse-phase HPLC analysis was carried out by using a Docosil B column $(4.6 \times 250 \mathrm{~mm}$; Senshu Scientific), and fractions were eluted with a gradient of acetonitrile in water (both containing $0.1 \%$ trifluoroacetic acid) at a flow rate of $1 \mathrm{ml} \mathrm{min}^{-1}$ at $40{ }^{\circ} \mathrm{C}$. The conditions of the gradient were $10-63 \%$ acetonitrile for $20 \mathrm{~min}$. UV absorbance was detected at 254 and $320 \mathrm{~nm}$ for $\mathbf{2}$ and 7, respectively; $\mathbf{2}$ and $\mathbf{7}$ were used to generate the standard curve for the quantification of the product. Steady-state parameters were determined by Hanes-Woolf plot (Supplementary Figure S3).

\section{Cytotoxicity assay}

A human promyelocytic leukemia cell line, HL-60 (RIKEN Cell Bank, Saitama, Japan), was cultured in RPMI 1640 (Life Technologies, Irvine, CA, USA) supplemented with $10 \%$ fetal bovine serum (Sigma-Aldrich, St Louis, MO, USA), $50 \mathrm{U} \mathrm{ml}^{-1}$ penicillin and $50 \mu \mathrm{g} \mathrm{ml}^{-1}$ streptomycin at $37^{\circ} \mathrm{C}$ in a humidified atmosphere that contained $5 \% \mathrm{CO}_{2}$. HL-60 cells $\left(1.5 \times 10^{4}\right.$ cells per well) were seeded in 96-well culture plates and exposed to test compounds for $48 \mathrm{~h}$. Cell growth was measured using Cell Count Reagent SF (Nacalai Tesque) as per the manufacturer's instructions. Briefly, the WST- 8 solution was added to each well, and the plates were incubated at $37^{\circ} \mathrm{C}$ for $1.5 \mathrm{~h}$. Cell growth was then measured at $450 \mathrm{~nm}$ on a microplate reader (Perkin-Elmer, Boston, MA, USA).

\section{RESULTS}

\section{Heterologous expression of $d p y A$ in S. coelicolor}

DpyA forms a distinct clade in a phylogenetic tree constructed from type III PKS enzymes, which were selected by BLAST search using the DpyA sequence as a query (Supplementary Figure S4). This indicates that DpyA is evolutionarily distinct from type III PKS enzymes, the catalytic properties of which have been characterized. To clarify its in vivo role, $d p y A$ was overexpressed in S. coelicolor $\mathrm{M} 1146^{20}$ by using a high-copy-number plasmid pIJ6021. ${ }^{19}$ S. coelicolor M1146/pIJ6021SRE2_11, a $d p y A$-overexpressing strain, accumulated compounds 1-4, as revealed by HPLC analysis (Figure 2a). Compounds 1-4 were not detected in a negative control culture, S. coelicolor M1146/pIJ6021 (Figure 2b). NMR and MS analyses of compounds 1-4 revealed that these compounds were alkyldihydropyrones with side chains that differed from each other (Figure 1). ${ }^{1} \mathrm{H}$ NMR-, ${ }^{13} \mathrm{C}$ NMR-, HMBC-, HSQC spectra and key HMBC coupling of compounds 1-4 are shown in Supplementary Figures S5-21. 


\section{In vitro analysis of recombinant DpyA}

In keeping with polyketide structure, alkyldihydropyrones would be expected to be composed of short-chain fatty acid, malonate and methylmalonate building blocks. We assume that fatty acid and malonate moieties of alkyldihydropyrones are derived from acyl carrier protein thioesters of $\beta$-hydroxyl acids, which are intermediates of fatty acid biosynthesis. ${ }^{21}$ It is known that germicidin synthase uses the acyl carrier protein thioester of $\beta$-keto acid as a starter substrate to synthesize 4-hydroxy-3-methyl-2-pyrone derivatives. ${ }^{22}$ $\mathrm{N}$-acetylcysteamine is an analogue of the phosphopantethienyl arm of holo-acyl carrier protein and CoA. The $\mathrm{N}$-acetylcysteamine ester is well accepted by PKSs as a substrate analogue of acyl carrier protein thioesters. $^{23,24}$ Therefore, we used 3-hydroxyoctanoic acid $S$ - $\left(2^{\prime}\right.$ acetamidoethyl) ester (5) as an analogue of the corresponding acyl carrier protein thioester (Figure 3). We also prepared 3-oxooctanoic acid $S$-( $2^{\prime}$-acetamidoethyl) ester (6) to compare the reactivity of DpyA against $\beta$-hydroxyl and $\beta$-keto substrates (Figure 3 ). As expected, $10 \mu \mathrm{M}(R)-\mathbf{5}$ was readily accepted as a starter substrate to give $(R)-\mathbf{2}$ (Figure 4a), although (S)-5 was a poor substrate for DpyA (Figure $4 \mathrm{~b}$ ). We also analyzed the optical purity of $\mathbf{5}$ to ascertain the proportion that remained unreacted. As expected, the consumption rate of $(R)-\mathbf{5}$ was larger than that of $(S)-\mathbf{5}$ (Supplementary Figure S22). We therefore conclude that $(R)-5$ is a native substrate of DpyA. Consistent with the in vivo result, which showed that 7 was not produced by $S$. coelicolor M1146/pIJ6021-SRE2_11 (Figure 2a), $10 \mu \mathrm{M}$ 6 was not used as a substrate by DpyA (Figure 4c). At higher concentrations $(100 \mu \mathrm{M}), 6$ was accepted as a substrate to give 4-hydroxy-3-methyl-6-pentyl-2H-pyran-2-one (7) (Supplementary Figure S23). The apparent $K_{\mathrm{m}}, k_{\mathrm{cat}}$ and $k_{\mathrm{cat}} / K_{\mathrm{m}}$ values of $(R)-5$ for 2 synthesis were $159 \pm 14 \mu \mathrm{M}, 3.54 \pm 0.16 \mathrm{~min}^{-1}$ and $22.5 \pm 1.3 \mathrm{~min}^{-1}$ $\mathrm{mM}^{-1}$ (mean \pm s.e., $n=3$ ), respectively. Whereas the apparent $K_{\mathrm{m}}, k_{\mathrm{cat}}$ and $k_{\mathrm{cat}} / K_{\mathrm{m}}$ values of 6 for 7 synthesis were $310 \pm 22 \mu \mathrm{M}$, $1.45 \pm 0.032 \mathrm{~min}^{-1}$ and $4.69 \pm 0.24 \mathrm{~min}^{-1} \mathrm{~mm}^{-1}$ (mean \pm s.e., $n=3$ ), respectively. The $k_{\text {cat }} / K_{\mathrm{m}}$ value of $(R)-5$ is five times higher than that of 6 , indicating that DpyA preferentially uses the $\beta$-hydroxyl substrate over the $\beta$-keto substrate. It is known that type III PKS is promiscuous and capable of reacting with several substrates. ${ }^{1}$ Similarly, when hexanoyl-CoA, malonyl-CoA and methylmalonylCoA were used as substrates, the reaction yielded very small amount of 7 with three unknown products at the substrate concentration of $100 \mu \mathrm{m}$ but not at $10 \mu \mathrm{M}$ (Supplementary Figure S24). These data do not indicate that 7 or triketide 8 is an intermediate of $\mathbf{2}$ in vivo, but merely reflect the promiscuity of DpyA.

\section{Biological activities of alkyldihydropyrones}

The cytotoxic activity of 1-4 was evaluated in vitro. Compounds $\mathbf{1}, \mathbf{2}$, 3 and 4 showed cytotoxicity against the leukemia cell line HL-60 with half-maximal inhibitory concentration values of 46.0, 52.1, 15.3 and $10.0 \mu \mathrm{g} \mathrm{ml}^{-1}$, respectively. The difference in activity level among alkyldihydropyrones may have resulted from the structure of the acyl side chain.

\section{DISSCUSSION}

In this study, we have characterized the catalytic properties of DpyA. We found that DpyA catalyzes the condensation of $\beta$-hydroxyacyl thioesters and methylmalonyl-CoA to synthesize dihydropyran compounds 1-4. While a number of type III PKSs are shown to catalyze the synthesis of pyrone ring compounds, ${ }^{4-6}$ there are no reports of type III PKS synthesizing dihydropyran compounds. DpyA was identified from the genome sequence data of $S$. reveromyceticus, and its function was characterized by heterologous expression and in vitro studies. This genome data-based approach for discovering a novel

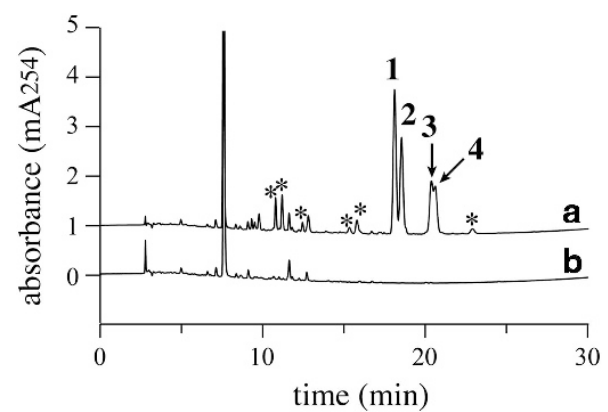

Figure 2 HPLC chromatograms of S. coelicolor M1146/pIJ6021-SRE2_11 (a) and S. coelicolor M1146/pIJ6021 (b). Uncharacterized minor peaks are marked with asterisks.

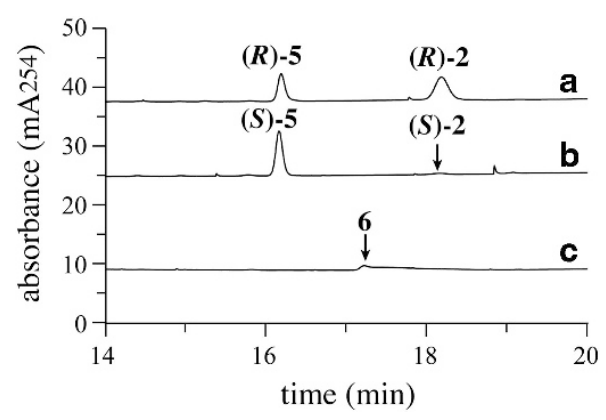

Figure 4 HPLC chromatograms of in vitro reactions of dihydropyrone synthase A (DpyA). (R)-5 (a), (S)-5 (b) and 6 (c) were used as starter substrates at a concentration of $10 \mu \mathrm{m}$.

a<smiles>CCCCCC(O)CC(=O)SCCNC(C)=O</smiles><smiles>CC1CCC1</smiles><smiles>CCCCCC(O)CC(=O)C(C)C(=O)SOCC</smiles><smiles>CCCCCC1CC(O)=C(C)C(=O)O1</smiles>
methylmalonyl-CoA 2

b<smiles>CCCCCC(=O)CC(=O)SCCNC(C)=O</smiles><smiles>CCC(C)C</smiles><smiles>CCCCCC(=O)CC(=O)C(C)C(=O)SCCC</smiles>
8 methylmalonyl-CoA

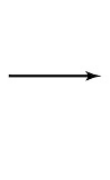<smiles>CCCCCc1cc(O)c(C)c(=O)o1</smiles>

Figure 3 Reactions of dihydropyrone synthase A (DpyA) from 5 (a) and 6 (b). 
biocatalyst is sometimes called 'genome mining', and has been used to characterize functionally several type III PKSs. ${ }^{5,6}$ In some cases, the catalyst identified by genome mining is not expressed under native conditions. This is the case for DpyA: we could not detect 1-4 in the culture of $S$. reveromyceticus (unpublished data). Alternatively, 1-4 may be transferred to other compounds by endogenous enzymes.

We suggest that the ring formation catalyzed by DpyA will proceed via nucleophilic attack at the thioester bond by the $\beta$-hydroxyl group. The possibility of dehydration between the $\beta$-hydroxyl group and the carboxylic acid, which is derived from hydrolysis of the thioester bond, was ruled out, as $\mathbf{2}$ was detected by HPLC analysis without acidifying the reaction mixture (data not shown). Furthermore, we could not detect any carboxylic acid compounds by HPLC (Figure 4a).

We could not separate 2 by chiral HPLC, hindering the determination of the enantiomeric purity of alkyldihydropyrones. However, we found that DpyA preferentially utilizes $(R)-5$ over $(S)-5$, as $42 \%$ of (R)-5 was consumed compared with $29 \%$ of $(S)-5$ (Supplementary Figure S21). Furthermore, $(S)-\mathbf{5}$ showed barely detectable amounts of the product $(S)-2$ (Figure $4 \mathrm{~b}$ ). FabG in the fatty acid biosynthesis pathway is known to catalyze 3-keto-acyl-CoA to $(R)$-3-hydroxyacylCoA. ${ }^{21}$ These data and evidence strongly suggest that the absolute configuration of the lactone moiety of alkyldihydropyrones is the $(R)$ form. Comparison of the optical rotation of $2\left([\alpha]_{D^{-}}^{20} 19\right)$ and the reported optical rotation $\left([\alpha]_{\mathrm{D}}^{25}+39\right)^{25}$ of $(S)$-5,6-dihydro-4-hydroxy3-methyl-6-undecyl-2H-pyrane-2-one, a structurally related compound of 2 , supports the idea that the absolute configuration of 2 is the $(R)$-form.

Compound 3 contains another chiral center in its 3-methylpentyl group, which is an intermediate of anteiso branched-chain fatty acids (Figure 1). It is known that anteiso branched-chain fatty acids are biosynthesized from L-isoleucine via $(S)$ - $\alpha$-methylbutyryl-CoA in Streptomyces. ${ }^{26}$ Therefore, we suggest that the absolute configuration of $\mathrm{C}^{\prime}$ position of $\mathbf{3}$ is the $(S)$-form. In summary, we have demonstrated that DpyA is a novel catalyst synthesizing alkyldihydropyrones, which exhibit weak cytotoxicity against the leukemia cell line HL-60.

\section{ACKNOWLEDGEMENTS}

We are grateful to Professor MJ Bibb for providing us S. coelicolor M1146. We are also grateful to Professor E Takano for providing us expression vectors pIJ6021 and pIJ4123. This work was, in part, supported by a Grant-in-Aid for Scientific Research on Innovative Areas (23108521) from the Ministry of Education, Culture, Sports, Science and Technology, the Naito Foundation and the Uehara Memorial Foundation.

1 Austin, M. B. \& Noel, J. P The chalcone synthase superfamily of type III polyketide synthases. Nat. Prod. Rep. 20, 79-110 (2003).

2 Katsuyama, Y., Kita, T., Funa, N. \& Horinouchi, S. Curcuminoid biosynthesis by two type III polyketide synthases in the herb Curcuma longa. J. Biol. Chem. 284, 11160-11170 (2009).
3 Funa, N. et al. A new pathway for polyketide synthesis in microorganisms. Nature 400, 897-899 (1999).

4 Funa, N., Funabashi, M., Ohnishi, Y. \& Horinouchi, S. Biosynthesis of hexahydroxyperylenequinone melanin via oxidative aryl coupling by cytochrome $P-450$ in Streptomyces griseus. J. Bacteriol. 187, 8149-8155 (2005).

5 Song, L. et al. Type III polyketide synthase $\beta$-ketoacyl-ACP starter unit and ethylmalonyl-CoA extender unit selectivity discovered by Streptomyces coelicolor genome mining. J. Am. Chem. Soc. 128, 14754-14755 (2006).

6 Funabashi, M., Funa, N. \& Horinouchi, S. Phenolic lipids synthesized by type III polyketide synthase confer penicillin resistance on Streptomyces griseus. J. Biol. Chem. 283, 13983-13991 (2008).

7 Pfeifer, V. et al. A polyketide synthase in glycopeptide biosynthesis: the biosynthesis of the non-proteinogenic amino acid (S)-3,5-dihydroxyphenylglycine. J. Biol. Chem. 276, 38370-38377 (2001).

8 Li, T.-L., Choroba, O. W., Hong, H., Williams, D. H. \& Spencer, J. B. Biosynthesis of the vancomycin group of antibiotics: characterization of a type III polyketide synthase in the pathway to (S)-3,5-dihydroxyphenylglycine. Chem. Commun. 2001, 2156-2157 (2001).

9 Chen, H., Tseng, C. C., Hubbard, B. K. \& Walsh, C. T. Glycopeptide antibiotic biosynthesis: enzymatic assembly of dedicated amino acid monomer (S)-3,5-dihydroxyphenylglycine. Proc. Natl Acad. Sci. USA 98, 14901-14906 (2001).

10 Wenzel, S. C., Bode, H. B., Kochems, I. \& Müller, R. A. Type I/type III polyketide synthase hybrid biosynthetic pathway for the structurally unique ansa compound kendomycin. Chembiochem 9, 2711-2721 (2008).

11 Tang, X. et al. A two-step sulfation in antibiotic biosynthesis requires a type III polyketide synthase. Nat. Chem. Biol. 10, 610-615 (2013).

12 Bentley, S. D. et al. Complete genome sequence of the model actinomycete Streptomyces coelicolor A3(2). Nature 417, 141-147 (2002).

$13 \mathrm{Ikeda}, \mathrm{H}$. et al. Complete genome sequence and comparative analysis of the industrial microorganism Streptomyces avermitilis. Nat. Biotechol. 21, 526-531 (2003).

14 Osada, H., Koshino, H., Isono, K., Takahashi, H. \& Kawanishi, G. Reveromycin A, a new antibiotic which inhibits the mitogenic activity of epidermal growth factor. J. Antibiot. 44, 259-261 (1991).

15 Woo, J.-T. et al. Reveromycin A, an agent for osteoporosis, inhibits bone resorption by inducing apoptosis specifically in osteoclasts. Proc. Natl Acad. Sci. USA 103, 4729-4734 (2006).

16 Muguruma, $\mathrm{H}$. et al. Reveromycin A inhibits osteolytic bone metastasis of small-cell lung cancer cells, SBC-5, through an antiosteoclastic activity. Clin. Cancer Res. 11, 8822-8828 (2005).

17 Sambrook, J., Maniatis, T. \& Fritsch, E. F. Molecular Cloning: A Laboratory Manual (Cold Spring Harbor, New York, NY, USA, 1989).

18 Kieser, T., Bibb, M. J., Buttner, K. F., Chater, K. F. \& Hopwood, D. A. Practical Streptomyces Genetics (The John Innes Foundation, Norwich, UK, 2000).

19 Takano, E., White, J., Thompson, C. J. \& Bibb, M. J Construction of thiostreptoninducible, high-copy-number expression vectors for use in Streptomyces spp. Gene 166, 133-137 (1995).

20 Gomez-Escribano, J. P. \& Bibb, M. J Engineering Streptomyces coelicolor for heterologous expression of secondary metabolite gene clusters. Microb. Biotechnol. 4, 207-215 (2011).

21 White, S. W., Zheng, J., Zhang, Y.-M. \& Rock, C. O. The structural biology of type II fatty acid biosynthesis. Annu. Rev. Biochem. 74, 791-831 (2005).

22 Grüschow, S., Buchholz, T. J., Seufert, W., Dordick, J. S. \& Sherman, D. H. Substrate profile analysis and ACP-mediated acyl transfer in Streptomyces coelicolor type III polyketide synthases. Chembiochem $\mathbf{8}, 863-868$ (2007).

23 Castonguay, R., He, W., Chen, A. Y., Khosla, C. \& Cane, D. E. Stereospecificity of ketoreductase domains of the 6-deoxyerythronolide B synthase. J. Am. Chem. Soc. 129, 13758-13769 (2007).

24 Itoh, T. et al. Actinorhodin biosynthesis: structural requirements for post-PKS tailoring intermediates revealed by functional analysis of ActVI-ORF1 reductase. Biochemistry 46, 8181-8188 (2007).

25 Fehr, M. J. et al. Asymmetric hydrogenation of substituted 2-pyrones. J. Org. Chem. 64, 5768-5776 (1999).

26 Denoya, C. D. et al. A second branched-chain $\alpha$-keto acid dehydrogenase gene cluster (bkdFGH) from Streptomyces avermitilis: its relationship to avermectin biosynthesis and the construction of a $b k d F$ mutant suitable for the production of novel antiparasitic avermectins. J. Bacteriol. 177, 3504-3511 (1995).

Supplementary Information accompanies the paper on The Journal of Antibiotics website (http://www.nature.com/ja) 